Arch. Tierz., Dummerstorf 51 (2008) 2, 143-148

Faculty of Veterinary Medicine, University of Firat, Elazig-TURKEY

SAMI SIMSEK, ARMAGAN ERDEM UTUK, ERGUN KOROGLU, NAZIR DUMANLI and ALI RISVANLI

\title{
Seroprevalence of Neospora caninum in repeat breeder dairy cows in Turkey* (short communication)
}

\begin{abstract}
Sera samples from 89 dairy cows with repeat breeder and 94 healthy pregnant dairy cows (controls) from Elazig province of eastern Turkey were tested for presence of Neospora caninum antibodies by use of a competitive enzyme linked immunosorbent assay (cELISA). Fifteen out of 183 cows tested (8.19\%) were found to be seropositive to $N$. caninum antibody. Overall, seroprevalence of $N$. caninum was significantly higher $(\mathrm{P}<0.05)$ in dairy cows with repeat breeder $(13.48 \%, 12 / 89)$ than in dairy cows with healthy pregnant $(3.19 \%, 3 / 94)$. There was no statistically significant relationship between seroprevalence and breed and age groups in cows with repeat breeder $(\mathrm{P}>0.05)$. In conclusion, the current study highlights the importance of $N$. caninum in cows with repeat breeder.
\end{abstract}

Key words: Neospora caninum, infertility, repeat breeder, seroprevalence.

\section{Zusammenfassung}

Titel der Arbeit: Seroprävalenz des Neospora caninum bei mehrfach kalbenden Kühen in der Türkei. (Kurzmitteilung)

Von Milchkühen dreier Rassen und einer Kreuzungspopulation aus der Elazig Provinz in der Osttürkei wurden Blutserumproben bei 89 bereits mehrfach kalbenden und 94 gesunden tragenden Kontrolltieren auf Antikörperresistenz gegen Neospora. caninum mittels ELISA getestet. Bei fünfzehn $=8,19 \%$ der 183 untersuchten Tiere wurden Antikörper nachgewiesen $(\mathrm{P}<0,05)$. Mit 13,48 \% (12 von 89 Tieren) war der Anteil mehrfach kalbenden Kühen signifikant höher als bei der Kontrollgruppe mit 3,19 \% (3/94). Keine signifikanten Beziehungen $(\mathrm{P}>0,05)$ ergaben sich zwischen der Serumprävalenz, der Rasse oder dem Alter der Tiere. Schlussfolgernd wird auf die Bedeutung von N. caninum bei mehrfach gebärenden Kühen hingewiesen.

Schlüsselwörter: Neospora caninum, Unfruchtbarkeit, mehrfach kalbende Kuh, Serumprävalenz

\section{Introduction}

Neospora caninum is an apicomplexan protozoon parasite and is an important cause of abortion and infertility in cattle (DUBEY and LINDSAY, 1996). It was detected for the first time in dogs in 1984 (BJERKAS et al., 1984) and was described as a new genus Neospora, type species N. caninum, in 1988 (DUBEY et al., 1988). The dog was recently shown to be a definitive host for $N$. caninum (McALLISTER et al., 1998).

There are several routes by which cattle may acquire Neospora infection, either by horizontal postnatal infection or by vertical transmission of the infection transplacentally during pregnancy (ANDERSON et al., 2000).

Cattle with serological evidence of infection have an increased risk of abortion (THURMAND and HIETALA, 1997). Abortion can occur at any stage of pregnancy and cow that aborted a previous pregnancy due to neosporosis can abort again, or give birth 
to diseased calves, calves with a subclinical $N$. caninum infection, or calves that are not infected (ANDERSON et al., 1995). Neospora caninum infection in mainly diagnosed in living animals by means of serological tests, such as the indirect fluorescent antibody (IFA) test, the agglutination test and enzyme-linked immunosorbent assays (ELISA). Serological test for $N$. caninum are needed to obtain information about the epidemiology of the life cycle, to differentiate between a recent and chronic infection and determine seroprevalence in herds, regions and countries (BJORKMAN and UGGLA, 1999; SADREBAZZAZ et al., 2004). Repeat breeding is one of the major infertility problems affecting reproductive efficiency and economy of milk production in dairy animals. The incidence of this condition has been reported to be 10-25\% (SHARMA et al., 1983). Causes of repeat breeding have been attributed to factors which are genetic, nutritional, hormonal, infection or managemental causes (SELVARAJU et al., 2002). In beef herds in Canada, cows with a titer for Neospora showed the following increase in odds ratios for various clinical problems: Infertility 2.5, abortion 5.7, stillbirth 2.8, culling 1.9 (HARTWIG, 2000). Thus, infertility is important as much as abortion at $N$. caninum infection.

In Turkey, bovine neosporosis was first reported average as $13.96 \%$ in dairy and beef cattle in eight different provinces of Central Anatolia in 2001 (BIYIKOGLU et al., 2001). AKTAS et al. (2005) reported the seroprevalence was mean $7.01 \%$ in healthy cattle and $3.12 \%$ in aborted cows in four different districts of eastern Turkey. The prevalence of infection was detected as $0 \%$ and $8.2 \%$ at local and imported (Simmental) breed of Turkey in the province of Kars, respectively (AKCA et al., 2005).

The present study investigates the prevalence of antibodies to $N$. caninum in dairy cows with repeat breeder and healthy pregnant in the province of Elazig in eastern Turkey and the detection of relationship between infertility but not abortion and neosporosis as well.

\section{Animals}

\section{Materials and Methods}

This study was carried out between June 2004 and December 2005. A total of 89 dairy cattle with a history of repeat breeder were selected for the study. They were clinically free of disease, aged 3-12 years and had no history of calving difficulty in the previous parturition. The animals had no gross abnormalities of reproductive tract on gynecological examination. They had normal estrus cycles and estrus period. They had failed to conceive after more than three but had clear vaginal mucus discharge at estrus. Another 94 dairy cattle were selected among from healthy pregnant cows. These animals had no infertility problem according to gynecological examinations and anamnesis. The ages of these cows were between 3-11 years. Both infertile and control groups consisted of different breed dairy cattle that Holstein, Simmental, Brown Swiss, and cross breeds (Table). All individual serum samples collected from Elazig province of eastern Turkey. 
Table: Seroprevalence of Neospora caninum in cows with groups and relationship between breed and age. (Serumprävalenz von Neospora caniunum bei Kühen beider Versuchsgruppen sowie Beziehung zu Rasse und Alter)

\begin{tabular}{lllllll}
\hline & $\begin{array}{l}\text { Repeat Breeder } \\
\text { Examined } \\
\text { (no) }\end{array}$ & $\begin{array}{l}\text { Infected } \\
\text { (no) }\end{array}$ & $\begin{array}{l}\text { Prevalence } \\
(\%)\end{array}$ & $\begin{array}{l}\text { Pregnant } \\
\text { Examined } \\
\text { (no) }\end{array}$ & $\begin{array}{l}\text { Infected } \\
\text { (no) }\end{array}$ & $\begin{array}{l}\text { Prevalence } \\
(\%)\end{array}$ \\
\hline Breed & & & & & & 0 \\
$\quad$ Holstein & 18 & 2 & 11.1 & 5 & 0 & 0 \\
$\quad$ Simmental & 14 & 2 & 14.2 & 7 & 0 & 2.04 \\
$\quad \begin{array}{l}\text { Brown Swiss } \\
\text { Crossbreed }\end{array}$ & 30 & 4 & 13.3 & 49 & 1 & 0.06 \\
Age & 27 & 4 & 14.8 & 33 & 2 & 0 \\
3 & 24 & 3 & 12.5 & 14 & 0 & 0 \\
4 & 20 & 3 & 15 & 34 & 1 & 0 \\
5 & 17 & 2 & 11.7 & 9 & 0 & 7.4 \\
6 & 10 & 2 & 20 & 10 & 0 & $3.19^{\mathrm{b}}$ \\
Total & 18 & 2 & 11.1 & 27 & 2 & 3 \\
\hline
\end{tabular}

The letters a and $\mathrm{b}$ denote a statistically significant $\left(\mathrm{P}<0.05, X^{2}: 6.43\right)$ difference of a similarly marked result in the same line

\section{Serum Samples}

Blood samples were collected from the jugular vein in sterile tubes. Sera were removed after centrifugation at $2000 \mathrm{rpm}$ for 5 minutes and stored $-20^{\circ} \mathrm{C}$ until serological tests were made.

\section{Serological Testing}

The antibodies to $N$. caninum in the sera were detected by a competitive cELISA using a commercially available test kit (VMRD, Pullman, USA). The tests were done following the instruction of manufacturer. The optical density (OD) values were determined with a microplate reader (Bio-Tek Instruments, USA) set at a wave length of $630 \mathrm{~nm}$. The percent inhibitions of antibodies to the antigens were calculated by using the formula:

Inhibition (\%) $=100-[($ Sample O.D. X 100) $\div($ Mean Negative Control O.D. $)]$

The samples with values of $\geq 30 \%$ inhibition were regarded as positive and those with the values of $<30 \%$ inhibitions were regarded as negative according to the manufacturer. Data analysis

Data management and statistical analysis by chi square tests were performed using SPSS 10.1 software for Windows.

\section{Results}

Table summarizes the result of the study. Fifteen out of 183 cows tested (8.19\%) were found to be seropositive to $N$. caninum antibody. Twelve of 89 cows (13.48\%) with a history of repeat breeder were seropositive to $N$. caninum antibody while the seropositivity rate was $3.19 \%(3 / 94)$ at healthy pregnant cows. This was significantly different from the seroprevalence obtained for the cows with repeat breeder $\left(\mathrm{P}<0.05, X^{2}\right.$ : 6.43). There was no statistically significant relationship between seroprevalence and breed and age groups in cows with repeat breeder $\left(\mathrm{P}>0.05, X^{2}: 0.13, X^{2}: 0.55\right)$. 


\section{Discussion}

Neospora caninum is considered to be one of the major causes of abortion and infertility in cattle worldwide although subclinical infection is very much more common (DUBEY, 1999). One study in California, USA found between $5 \%$ and $15 \%$ pregnancies ended in abortions each year and about one-third of the abortions were caused by $N$. caninum (BARR et al., 1998). CHI et al. (2002) reported that total annual cost for an average, infected, 50 cow herds were \$ 2304 for neosporosis.

Elazig where this study was carried out has important cattle population in Turkey. The high abortion and infertility rate in this area causes considerable economic loss and is the most important threat to the livelihood of its farmers.

In the present study, the seroprevalence was estimated in cows with repeat breeder and healthy including Holstein, Simmental, Brown Swiss and Crossbred. Twelve of the sera obtained from 89 cows with repeat breeder had antibodies to $N$. caninum (13.48\%). Highest seropositivity was detected at crossbred (14.8\%) following Simmental (14.2\%), Brown Swiss (13.3\%) and Holstein (11.1\%). AKCA et al. (2005) could not detect any antibody response against 228 local breeds of cows with a history of recent abortion. In contrast, AKCA et al. (2005) reported that $8.2 \%$ of the Simmental breed cows, randomly selected from amongst the original imports and subsequent generation were seropositive for $N$. caninum in the province of Kars in north-eastern Turkey. SEVGILI et al. (2005), used cELISA for detecting of $N$. caninum antibody in 305 cows from Sanliurfa in southeast Turkey. SEVGILI et al. (2005) found 7.5\% seropositivity and could not detect any significant differences among origin, breed and age $(\mathrm{P}>0.05)$. AKTAS et al. (2005) investigated the presence of $N$. caninum antibody in cattle in Elazig, Malatya, Mus and Bingol provinces where from eastern Turkey. Serum samples from 513 cattle with healthy and 32 cows with history of aborting. As a result seropositivity rates have been found 15\% in Elazig, 4\% in Malatya, 4.86\% in Mus and 4.69\% in Bingol by cELISA. Only one of the 32 cows (3.12\%) with aborting has been found to be positive against $N$. caninum. Although, AKTAS et al. (2005) reported the highest seropositivity in Simmental breed, they could not detect any statistical relationship between seroprevalence and breed groups in cows such as us $\left(\mathrm{P}>0.05, X^{2:} 0.13\right)$. Furthermore, the present study showed that $13.48 \%(12 / 89)$ of cows with repeat breeder were seropositive to $N$. caninum seropositivity rate was similar with the other (AKTAS et al., 2005) results for Elazig province.

As a part of the very precise immunological balance that pertains in the placenta, beneficial maternal cytokines such as interleukin (IL)-10 and transforming growth factor (TGF)- $\beta$ predominate, whereas potentially destructive cytokines such as IL-2, IL-12, interferon (IFN)- $\gamma$ and tumor necrosis factor (TNF)- $\alpha$ are restricted. Therefore, the immunological balance that has evolved within this unique tissue to allow the mother to nurture an allograft might also favor certain microorganisms, including $N$. caninum. Any inflammatory response elicited by tachyzoite invasion and multiplication in maternal and foetal placental cells might then stimulate an inappropriate immune reaction (ENTRICAN, 2002; BUXTON et al., 2002) that could play a part in a early embryo loses and abortion. Thus, the main reason of high seropositivity in cows with repeat breeding may be related to immunological response correlate with $N$. caninum. 
The life cycle of $N$. caninum has been demonstrated to consist of vertical or transplacental transmission, and horizontal or oral transmission (DUBEY, 1999; ANDERSON et al., 1997). The parasite is transmitted vertically from dam to calf (AKCA et al., 2005; ANDERSON et al., 1997). Vertical transmission of the parasite does not always cause abortion but rather results in apparently healthy but congenitally infected cows, thus the infection maintaining in the herd (AKCA et al., 2005). In contrast to vertical transmission, horizontal one involves a two-host life cycle where by the cow is infected from the ingestion of coccidial oocyst stages shed by the definitive host (AKCA et al., 2005). Dogs are known to be a definitive host and produce oocyst in their faces after ingesting infected meat (McALLISTER et al., 1998). There is only one published report available in Turkey that indicated 10\% seropositivity in 150 dogs examined by indirect fluorescent antibody test in two provinces of Turkey (COSKUN et al., 2000). Therefore, we believe that further studies are needed to determine the prevalence and incidence of Neosporosis in dogs in the province of Elazig in order to detect the role of dogs in the epidemiology of the infection in cattle in the region.

In conclusion, the current study highlights the importance of $N$. caninum in cows with repeat breeding.

\section{References}

AKCA, A.; GOKCE, H.I.; GUY, C.S.; McGARRY, J.W.; WILLIAMS, D.J.L.:

Prevalence of antibodies to Neospora caninum in local and imported cattle breeds in the Kars province of Turkey. Res. Vet. Sci. 78 (2005), 123-126

AKTAS, M.; SAKI, C.E.; ALTAY, K.; SIMSEK, S.; UTUK, A.E.; KOROGLU, E.; DUMANLI, N.:

Survey of Neospora caninum in cattle in some provinces in the Eastern Anatolian Region. Acta Parasit. Turcica. 29 (2005), 22-25

ANDERSON, M.L.; ANDRIANARIVO, A.G.; CONRAD, P.A.:

Neosporosis in cattle. Anim. Rep. Sci. 60-61 (2000), 417-431

ANDERSON, M.L.; PALMER, C.W.; THURMOND, M.C.; PICANSO, J.P.; BLANCHARD, P.C.;

BREITMEYER, R.E.; .LAYTON, A.W.; McALLISTER, M.; DAFT, B.; KINDE H.:

Evaluation of abortions in cattle attributable to neosporosis in selected dairy herds in California. J. Am. Vet. Med. Assoc. 207 (1995), 1206-1210

ANDERSON, M.L.; REYNOLDS, J.P.; ROWE, J.D.; SVERLOW, K.W.; PACKHAM, A.E.; BARR, B.C.; CONRAD, P.C.:

Evidence of vertical transmission of Neospora sp. infection in dairy cattle. J. Am. Vet. Med. Assoc. 210 (1997), 1169-1172

BARR, B.C.; DUBEY, J.P.; LINDSAY, D.S.; REYNOLDS, J.P.; WELLS, S.J.:

Neosporosis: its prevalence and economic impact. Suppl. Compend. Contin. Educ. Pract. Vet. 20 (1998), 116

BIYIKOGLU, G.; AKSOY, E.; BOZKIR, M.; KUCUKAYAN, U.; ERTURK, A.: Investigation of Neospora caninum in cattle in Central Anatolia Region of Turkey. XII. National Congress of Parasitology. Elazig. Turkey. (2001), p78.

BJERKAS, I.; MOHN, S.F.; PRESTHUS, J.: Unidentified cyst-forming sporozoon causing encephalomyelitis and myositis in dogs. Z. Parasitenkd. 70 (1984), 271-274

BJORKMAN, C.; UGGLA A.:

Serological diagnosis of Neospora caninum infection. Int. J. Parasitol. 29 (1999), 1497-1507

BUXTON, D.; McALLISTER, M.M.; DUBEY, J.P.:

The comparative pathogenesis of neosporosis. Trends in Parasit. 18 (2002), 546-552

CHI, J.; Van LEEUWEN, J.A.; WEERSINK, A.; KEFE, G.P.:

Direct production losses and treatment costs from bovine viral diarrhoea virus, bovine leukosis virus, Mycobacterium avium subspecies paratuberculosis, and Neospora caninum. Prev. Vet. Med. 55 (2002), 137-153 
COSKUN, S.Z.; AYDIN, L.; BAUER, C.:

DUBEY, J.P.

Seroprevalence of Neospora caninum infection in domestic dogs in Turkey. Vet Rec. 146 (2000), 649

Neosporosis in cattle, biology and economic impact. J. Am. Vet. Med. Assoc. 214 (1999), 1160-1163.

DUBEY, J.P.; LINDSAY, D.S.:

A review of Neospora caninum and Neosporosis. Vet. Parasitol. 67 (1996), 1-59

DUBEY, J.P.; COUPENTER, J.L.; SPEER, L.A.; TOPPER, M.J.; UGGLA, A.:

ENTRICAN, G. Newly recognized fatal protozoon disease of dogs, J. Am. Vet. Med. Assoc. 192 (1988), 1269-1285

Immune regulation during pregnancy and host-pathogen interactions in infectious abortion. J. Comp. Pathol. 126 (2002), 79-94

HARTWIG, N.R.:

Infectious diseases that affect cattle fertility. Beef Cattle Breeding Management Seminar. Iowa State University, USA, 2000

McALLISTER, M.M.; DUBEY, J.P.; LINDSAY, D.S.; JOLLEY, W.R.; WILLS, R.A.; McGUIRE, A.M.: Dogs are definitive host of Neospora caninum. Int. J. Parasitol. 28 (1998), 1473-1478

SADREBAZZAZ, A.; HADDADZADEH, H.; ESMAILNIA, K.; HABIBI, G.; VOJGANI, M.; HASHENIFESHARAKI, R.:

Serological prevalence of Neospora caninum in healthy and aborted dairy cattle in Mashad, Iran. Vet. Parasitol. 124 (2004), 201-204

SELVARAJU, S.; AGARWAL, S.K.; KARCHE, S.D.; SRIVASTAVA, S.K.; MAJUMDAR, A.C.; SHANKER, U.: Fertility responses and hormonal profiles in repeat breeding cows treated with insulin. Anim. Reprod. Sci. 73 (2002), 141-149

SEVGILI, M.; ALTAS, M.G.; KESKIN, O.:

Seroprevalence of Neospora caninum in cattle in the province of Sanliurfa. Tr. J. Vet. Anim. Sci. 29 (2005), 127-130

SHARMA, N.C.; LUKTUKE, S.N.; GUPTA, S.K.:

Incidence of repeat breeding in crossbreed cows. Indian J. Anim. Reprod. 3 (1983), 110-112

THURMAND, M.C.; HIETALA S.K.:

Effect of congenitally acquired Neospora caninum infection on risk of abortions and subsequent abortions in dairy cattle, Am. J. Res. 58 (1997), 1381-1385

*This study was supported by a grant from The Scientific and Technical Research Council of Turkey (TUBITAK).

Received: 2006-11-29

Accepted: 2008-01-30

Authors address

Assoc. Prof. SAMI SIMSEK, DVM ARMAGAN ERDEM UTUK, Prof. ERGUN KOROGLU, Prof. NAZIR DUMANLI

Department of Parasitology, Faculty of Veterinary Medicine, University of Firat, 23119, ElazigTURKEY

\author{
Corresponding Author: \\ Assoc. Prof. Ali Risvanli \\ Department of Obstetrics and Gynecology, Faculty of Veterinary Medicine, University of Firat, \\ 23119, Elazig-TURKEY \\ phone: + 9042423700 00/3845 \\ fax: + 904242388173 \\ email: arisvanli@yahoo.com
}

